\title{
The influence of the interception process on the precipitation quality in a catchment covered by subtropical Atlantic Forest
}

\section{Influência do processo de interceptação na qualidade da água da chuva em uma bacia coberta por floresta Ombrófila Mista}

\author{
João Henrique Macedo Sá1, Pedro Luiz Borges Chaffe ${ }^{1}$ and Matthieu Jack Joseph Quillet ${ }^{2}$ \\ ${ }^{1}$ Universidade Federal de Santa Catarina, Florianópolis, SC, Brazil \\ ${ }^{2}$ Université Joseph Fourier, Grenoble, France \\ E-mails: joao.h.sa@posgrad.ufsc.br (JHMS), pedro.chaffe@ufsc.br (PLBC), matthieu-quillet.06@hotmail.fr (MJJQ)
}

Received: April 11, 2016 - Revised: July 05, 2016 - Accepted: August 17, 2016

\begin{abstract}
The interception process is responsible for the spatial and temporal redistribution of the precipitation that reaches the ground. The contact of the precipitation with the canopy influences on the water quality, increasing the concentration of various nutrients in the throughfall $(T f)$ and stemflow $(S f)$. The objective of this study was to assess the influence of the interception process on the precipitation quality in a catchment covered by Mixed Ombrophilous Forest. The precipitation $(P)$ monitoring consisted of two rain gauges installed outside the basin. Six gauges were installed within the basin for $T f$ monitoring. The $S f$ monitoring was conducted in nine trees. Water sampled at all points was analyzed for color, conductivity, $\mathrm{pH}$, turbidity, and total dissolved solids. The concentrations of Nitrate $\left(\mathrm{NO}_{3}^{-}\right)$, Chloride $(\mathrm{Cl})$, Phosphate $\left(\mathrm{PO}_{4}^{3-}\right)$, Sulfate $\left(\mathrm{SO}_{4}^{2-}\right)$, Acetate $\left(\mathrm{CH}_{3} \mathrm{CO}_{2}{ }^{-}\right)$and Calcium $\left(\mathrm{Ca}^{2+}\right)$ ions were measured in five points, i.e., one precipitation, two throughfall and two stemflow. Measured precipitation, throughfall and stemflow during the period were $652.1 \mathrm{~mm}, 584.5 \mathrm{~mm}(89,6 \% \mathrm{P})$ and $2.6 \mathrm{~mm}(0,4 \% \mathrm{P})$, respectively. Total interception loss was $65 \mathrm{~mm}$, corresponding to $10 \%$ of the total precipitation. The highest values of the physicochemical parameters were found in the Sf and the Tf. The pH was lower in the $S f$, and it decreases with the diameter at breast height. There was no significant relationship between the physicochemical parameters and the canopy cover fraction. The analysis shows the significant difference in the water quality of the precipitation that reaches the ground after being intercepted.
\end{abstract}

Keywords: Atlantic Forest; Precipitation interception; Precipitation water quality.

\section{RESUMO}

O processo de interceptação é responsável pela redistribuição espacial e temporal da água da chuva que é interceptada antes de chegar no solo. O contato da água da chuva com o dossel e os troncos das árvores altera a qualidade da mesma, aumentando a concentração de diversos nutrientes na chuva interna ( $T f$ ) e no escoamento pelo tronco ( $S f)$. Este trabalho tem por objetivo analisar a influência do processo de interceptação na qualidade da água da chuva em uma bacia coberta por floresta Ombrófila Mista. O monitoramento da chuva externa $(P)$ foi realizado com dois pluviômetros instalados fora da bacia. Seis pluviômetros foram instalados dentro da floresta para o monitoramento da $T f$. O monitoramento do $S f$ foi realizado em noves árvores. Em todos os pontos foram medidos os parâmetros de cor aparente, condutividade, $\mathrm{pH}$, turbidez e teor de sólidos totais. As concentrações de íons de $\mathrm{Nitrato}\left(\mathrm{NO}_{3}{ }^{-}\right)$, Cloreto $\left(\mathrm{Cl}{ }^{-}\right)$, Fosfato $\left(\mathrm{PO}_{4}^{3-}\right)$, Sulfato $\left(\mathrm{SO}_{4}^{2-}\right)$, Acetato $\left(\mathrm{CH}_{3} \mathrm{CO}_{2}{ }^{-}\right)$e Cálcio $\left(\mathrm{Ca}^{2+}\right)$ foram monitoradas em cincos pontos, i.e., um ponto de $P$, dois pontos de $T f$ e dois pontos de $S f$. A $P$ foi de $652,1 \mathrm{~mm}$, a $T f$ foi de $584,5 \mathrm{~mm}(89,6 \%$ da $P$ ) e o $S f$ foi de $2,6 \mathrm{~mm}(0,4 \%$ da $P$ ). A perda por interceptação da copa foi de $65 \mathrm{~mm}$, correspondendo a $10 \%$ da chuva externa. As maiores concentrações dos parâmetros físico-químicos analisados ocorreram no $S f$ e na $T f$. $\mathrm{O}$ pH monitorado foi menor no $S f$, decrescendo com o diâmetro na altura do peito. Não foi encontrada nenhuma relação significativa entre os parâmetros físico-químicos e o índice de cobertura do dossel. As análises mostraram que o processo de interceptação tem influência significativa na qualidade da água da chuva.

Palavras-chave: Floresta Ombrófila Mista; Interceptação da chuva; Qualidade da água da chuva. 


\section{INTRODUCTION}

Before reaching the ground, precipitation falling on a forest passes through the interception process. Some water is temporarily retained in the canopy and evaporates, and this is considered interception loss. The remainder goes to the ground and may fall as canopy drip or flow as stemflow. (DAVID; VALENTE; GASH, 2005; GERRITS; SAVENIJE, 2011). The interception redistributes the precipitation in space and time, influencing the quantity and quality of water (BOUTEN; HEIMOVAARA; TIKTAK, 1992; KEIM; SKAUGSET; WEILER, 2005; STAELENS et al., 2006; SOUZA et al., 2007; WUYTS et al., 2008). Rainfall interception by the vegetation has a great importance for the geochemical cycling of nutrients in crops and tropical forests (LACLAU et al., 2003; FORTI et al., 2005).

The water balance in native forests is influenced by the diversity of ecosystems and the forest canopy structure (DÍAZ; BIGELOW; ARMESTO, 2007; ÁVILA et al., 2014). On average, the interception loss is $20-40 \%$ of the total precipitation (OLIVEIRA JUNIOR; DIAS, 2005; MOURA et al., 2009; TOGASHI; MONTEZUMA; LEITE, 2012; FREITAS et al., 2013; LORENZON; DIAS; LEITE, 2013; TONELLO et al., 2014; SÁ; CHAFFE; OLIVEIRA, 2015).

The canopy architecture leaf area index, density and trees structures are some factors that are responsible for different interactions between the rain and the forest ecosystem (ARCOVA; CICCO; ROCHA, 2003; MELO; MIRANDA; DURIGAN, 2007; CALDATO; SCHUMACHER, 2013). The throughfall quality is given by three factors: washing of deposited elements on leaves (dry deposition); changes that occur directly in the treetops through leaching of nutrients; and the absorption of direct nutrients from leaves (ARCOVA; CICCO, 1987; KRAMER; BOYER, 1995).

The Rainfall contact with the canopy increases the ammonia $\left(\mathrm{N}^{-} \mathrm{NH}_{4}^{+}\right)$, phosphate $\left(\mathrm{PO}_{4}^{3-}\right)$, potassium $\left(\mathrm{K}^{+}\right)$, calcium $\left(\mathrm{Ca}^{2+}\right)$, magnesium $\left(\mathrm{Mg}^{2+}\right)$ and sodium $\left(\mathrm{Na}^{+}\right)$concentrations both in throughfall and stemflow (KOICHIRO et al., 2001; BALIEIRO et al., 2007; SCHEER, 2009; SOUZA; MARQUES, 2010; DINIZ et al., 2013). The most common chemicals found in precipitation are: cations (e.g. $\mathrm{Ca}^{2+}, \mathrm{Na}^{+}, \mathrm{K}^{+}, \mathrm{Mg}^{2+}$ ) and anions (e.g. $\mathrm{SO}_{4}^{2-}, \mathrm{HCO}_{3}^{-}, \mathrm{NO}_{3}^{-}, \mathrm{Cl}^{-}, \mathrm{PO}_{4}^{3-}$ ) (DINGMAN; 2002; CONCEIÇÃO et al., 2013). These elements can be derived from: salt spray (e.g. $\mathrm{Na}^{+}, \mathrm{Cl}, \mathrm{Mg}^{2+}$ and $\mathrm{K}^{+}$), terrestrial aerosols, dust and soil organic emissions (e.g. $\mathrm{Ca}^{2+}, \mathrm{P}^{2}$ and $\mathrm{NO}^{3-}$ ), and anthropogenic sources (ARCOVA; CICCO; SHIMOMICHI, 1993).

The Atlantic Forest is one of the major biomes in Brazil, extending throughout the eastern portion of the territory. This biome is recognized as one of the 25 areas of greatest biodiversity in the world, with more than $60 \%$ of all the terrestrial species (MYRES et al., 2000; BATALHA FILHO; MIYAKI, 2011). Only $10 \%$ (72,405 hectares) of the federal conservation units are in Subtropical Atlantic Forest (PIRES; ZENI JUNIOR; GAULKE, 2012).

In the Atlantic Forest, the interception loss varies from 8.4 to $20.6 \%$. In Brazil, there are few studies of the precipitation quality in the Amazon and Atlantic Forest (GIGLIO; KOBIYAMA, 2013). The objective of this study is to analyze the influence of the interception process in the precipitation quality in a watershed covered by Subtropical Atlantic Forest.

\section{MATERIALS AND METHODS}

\section{Study area}

Araponga catchment is situated in Rio Negrinho city, north of Santa Catarina State, southern Brazil (Figure 1). The road around the experimental catchment is not paved. The catchment has 5.3 hectares and the altitude varies from $880 \mathrm{~m}$ to $1006 \mathrm{~m}$ above the sea level. It is classified as second order and is completely covered by Subtropical Atlantic Forest (MOTA, 2012).

Rio Negrinho city is situated on the Paraná sedimentary basin, in the geomorphological unit Porch Mafra. The dominant soils in the region are from the Cambisol group, which are derived from sedimentary rocks and from soils characterized by an incipient B horizon, undeveloped and presenting clay of high activity and high saturation bases (MOSER, 1990).

\section{Rainfall, throughfall and stemflow data}

The water samples were collected at least once a month from 06/05/2014 until 11/11/2014. Precipitation $(P)$ and throughfall (Tf) were monitored using hand made polyethylene terephthalate (PET) gauges. The hand-made rain gauges are made up of a funnel with an opening of $0.0195 \mathrm{~m}^{2}$ and a 5 liter containers (Figure 1a). To check the homogeneity of the precipitation on the experimental catchment, two hand-made rain gauges ( $P 1$ and $P 2)$ were installed along the road bordering the catchment (GIGLIO, 2013). Throughfall and canopy cover index (CCI) were monitored at 6 points. Each point was named by $T f$ combined with the average value of CCI as shown in Figure 1.

Stemflow $(S f)$ was monitored on both margins of the main stream (Figure 1). A portion of the collectors was located on the east side of the river $(S f-e)$ and the other one on the west side $(S f-w)$. The slopes of the two margins are similar and the vegetation cover is composed of larger trees than elsewhere in the basin (GIGLIO, 2013). The stemflow volume was collected using spiral collar collectors, and stored in PET bottles of 5 and 10 liters (Figure 1c).

The naming of each point of stemflow was given by $S f$ plus the value of the diameter at breast height (DBH) and according to the side the portion was on relative to the river (i.e. east side is $S f-e$ and the west side is $S f-w)$. On the west side of the river $(S f-w)$ four trees were monitored: one Tabebuia cassionoides $(\mathrm{DBH}=1.9 \mathrm{~cm})$, one Myrtaceae sp.2 (DBH $=23.2 \mathrm{~cm})$, one Cupania vernalis $(\mathrm{DBH}=14.3 \mathrm{~cm})$ and one Myrsine coriacea $(\mathrm{DBH}=16.7 \mathrm{~cm})$. On the east side of the river (Sf-e) five trees were monitored: two Vernonanthura discolor (DBH $=31.8$ and $21.6 \mathrm{~cm})$, one Prumus myrtifolia $(\mathrm{DBH}=13.1 \mathrm{~cm})$, one Guapira opposita $(\mathrm{DBH}=17.5 \mathrm{~cm})$ and one tree was not identified (DBH $2.9 \mathrm{~cm})$. The estimate of the stemflow was given by the measured volume divided by the area of the projection of the corresponding tree canopy.

The CCI was calculated from photographs taken from tree canopies. The photographs were converted to gray scale and then transformed into black and white binary images. The white pixels $\left(N_{\mathrm{w}}\right)$ represent the open class and the black pixels $\left(N_{\mathrm{b}}\right)$ representing the covered class (NASCIMENTO; FAGG; FAGG, 2007). The Equation 1 was used for calculating the CCI: 


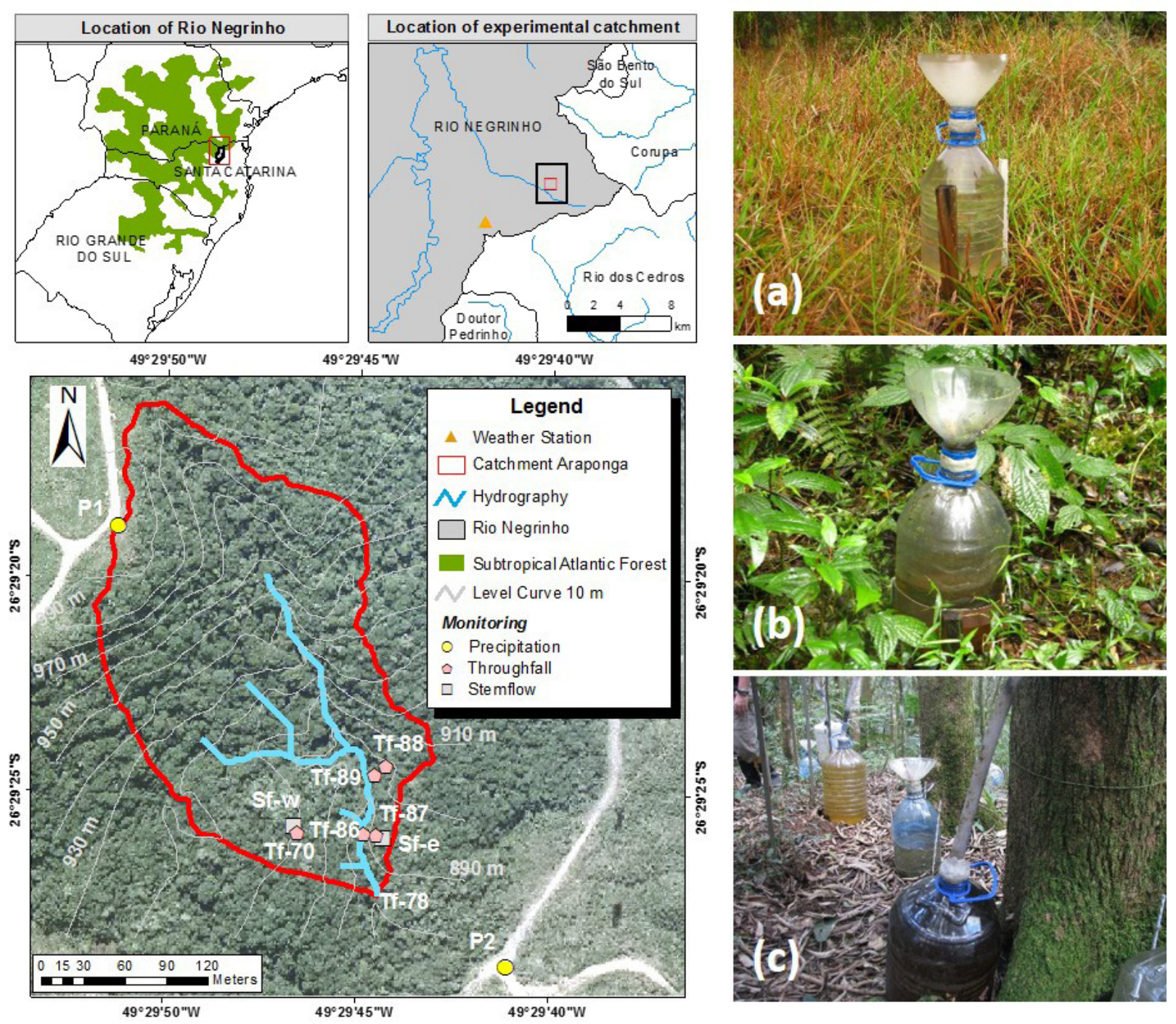

Figure 1. Location of the monitoring points. (a) Rainfall collector, (b) Throughfall collector and (c) Stemflow collector.

$$
C C I=\frac{N_{\mathrm{b}}}{N_{\mathrm{b}}+N_{\mathrm{w}}} \cdot 100
$$

where CCI is the canopy cover index; $N_{\mathrm{b}}$ is the number of black pixels; and $N_{\mathrm{w}}$ is the number of white pixels.

\section{Physicochemical water analysis}

The $\mathrm{pH}$ and electrical conductivity were measured in situ with colorimetric tape and a portable conductivity meter. Water apparent color was measured with an ASTM (APHA, 2005) laboratory colorimeter. The determination of turbidity was made with the HACH-2100N Turbidimeter. The total solids content (St) was measured by weighing a fiberglass membrane before $\left(M_{0}\right)$ and after $\left(M_{1}\right)$ filtering a water volume $(V)$ and drying the membrane in an oven. The $S t$ is calculated according to Equation 2.

$$
S t=\frac{\left(M_{1}-M_{0}\right) 10^{6}}{V}
$$

where $S t$ is the total solids (mg. $\left.\mathrm{L}^{-1}\right) ; M_{0}$ is the mass of the fiberglass membrane (g); $M_{1}$ is the mass of the fiberglass membrane with dry residue (g) at $103-105{ }^{\circ} \mathrm{C}$ and $V$ is the sample volume which was filtered (ml).

\section{Cluster and correlation analysis}

Cluster and correlation analysis were performed using the transformed and standardized variables. The hierarchical clustering was performed by using the complete linkage clustering method and the Euclidean distance as distance measure. The transformed variables were standardized according to Equation 3:

$x_{p}=\frac{x_{i}-x_{m}}{s}$

where $\chi_{\mathrm{p}}$ is the standard variable; $\chi_{\mathrm{i}}$ is the original value of the variable; $x_{\mathrm{m}}$ is the average of the variable and $s$ is the standard deviation.

In the exploratory analysis we checked charts and histograms in order to verify if the variables followed the normal distribution. 
The variables that were not normally distributed were transformed using a mathematical transformation (e.g. natural logarithm or $x^{3}$ ).

The correlation analysis shows how two variables vary together, checking the intensity and the direction of the linear relationship (positive: $p=1$ and negative: $p=-1$ ) or nonlinearity between these variables (NAGHETTINI; PINTO, 2007).

Pearson's parametric and Spearman's non-parametric correlations coefficients were considered in this study. The nonparametric test does not require variables with normal distribution, but has the disadvantage of not finding much difference between the data, when in fact these differences might exist (NAGHETTINI; PINTO, 2007).

The Pearson's correlation measures the degree of linear relationship between two variables. The Spearman's correlation evaluates a monotonic function of the relationship. The calculation of the Pearson's correlation coefficient is shown in Equation (4):

$$
p=\frac{\sum_{\mathrm{i}=l}^{\mathrm{n}}\left(x_{\mathrm{i}}-x_{\mathrm{m}}\right)\left(y_{\mathrm{i}}-y_{\mathrm{m}}\right)}{\sqrt{\sum_{\mathrm{i}=I}^{\mathrm{n}}\left(x_{\mathrm{i}}-x_{\mathrm{m}}\right)^{2}} \sqrt{\sum_{i=l}^{\mathrm{n}}\left(y_{\mathrm{i}}-y_{\mathrm{m}}\right)^{2}}}
$$

where $x_{1}, x_{2}, \ldots, x_{\mathrm{n}}$, and $y_{1}, y_{2}, \ldots, y_{\mathrm{n}}$ are the values of both variables; $x_{\mathrm{m}}$ and $y_{\mathrm{m}}$ are the averages of both variables. All the statistical analysis were performed in MATLAB (MathWorks, Natick, MA).

\section{Ions analysis}

Five of the 17 monitored points were selected for ions analysis. Were sampled two stemflow points ( $S f-02 w$ and $S f-32 e$ ) two throughfall points (Tf-87 and Tf-88) and one gross rainfall point $(P 1)$, the other points were not considered due to the lack of material availability to realize the analysis.

To determine the concentration of calcium $\left(\mathrm{Ca}^{2+}\right)$ it was prepared an acid digestion in order to obtain aqueous samples according to the method 3010A (APHA, 2005). The $\mathrm{Ca}^{2+}$ concentrations were determined in triplicate with an atomic absorption spectrometer Spectro Flame AA 50B.

The concentrations of nutrients and minerals $\left(\mathrm{Cl}^{-}, \mathrm{SO}_{4}^{2-}\right.$, $\mathrm{PO}_{4}^{3-}, \mathrm{NO}_{2}, \mathrm{NO}_{3}, \mathrm{CH}_{3} \mathrm{CO}_{2}^{-}$) were analyzed by ion chromatography with Thermo Scientific Dionex equipment.

\section{RESULTS AND DISCUSSION}

\section{Rainfall, throughfall and stemflow data}

Gross rainfall $(P)$, throughfall $(T f)$ and stemflow $(S f)$ volumes were monitored from $06 / 05 / 2014$ to $11 / 11 / 2014$. Gross rainfall measured in $P 1$ and in $P 2$ were very similar and can be considered homogeneous in the catchment (Figure 2). Water quality was not analyzed for three of monitored periods (Figure 3). In the period between 05 June to 26 July the collection bottles were all full of water, so the quantitative analysis was not held but the qualitative analysis - physicochemical and ions were.

Gross rainfall during the period was $652 \mathrm{~mm}$, and the throughfall accounted for $89.6 \%(584 \mathrm{~mm})$ of the total precipitation amount. The proportion of throughfall relative to the precipitation was in the range of the values found in the literature, from 70.0 to $94.4 \%$ of the precipitation for Atlantic
Forest forests (CASTRO et al., 1983; OLIVEIRA JUNIOR; DIAS, 2005; THOMAZ, 2005; ALVEZ et al., 2007, SOUZA et al., 2007, CICCO et al., 1988; MOURA et al., 2009; SARI; PAIVA; PAIVA, 2015, 2016). The canopy interception loss was $65 \mathrm{~mm}$, corresponding to $10 \%$ of precipitation (Figure 3). which is in the range of 8.4 to $20.6 \%$ observed in Atlantic Forests (GIGLIO; KOBIYAMA, 2013).

The average stemflow for each monitored period ranged from 0.01 to $4 \mathrm{~mm}$, corresponding to 0.02 and $3.00 \%$ of the gross rainfall. In studies conducted in the Atlantic Forest the highest

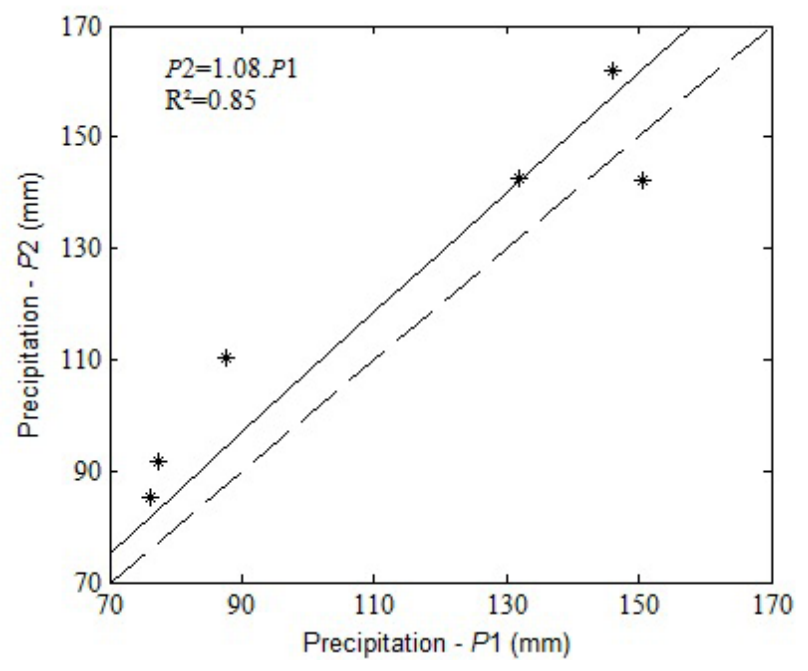

Figure 2. Relationship between the precipitation monitored at two points out of the catchment ( $P 1$ and $P 2)$. The continuous line represents the regression of the points of the precipitation and the dashed line represents a ratio of $1: 1$

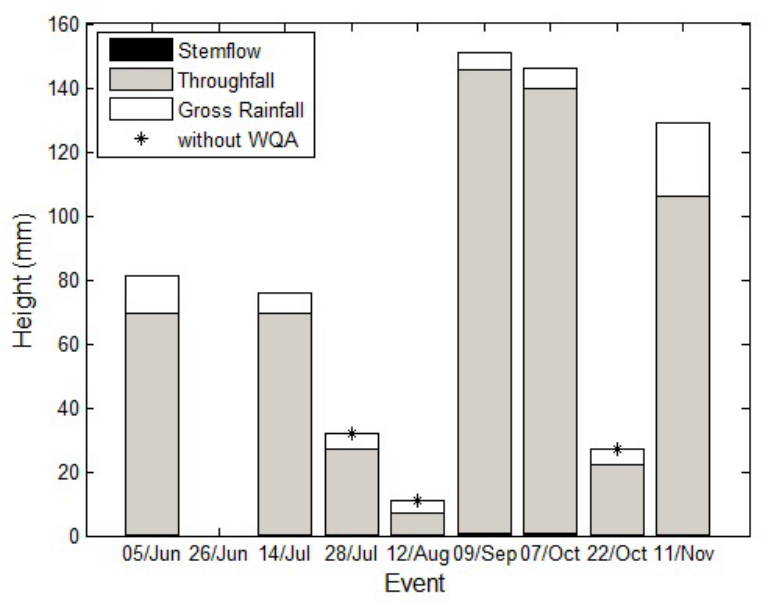

Figure 3. Measure Gross Rainfall $(P)$, throughfall $(T f)$ and the stemflow $(S f)$ recorded in each study period. $*$ periods without water quality analysis. 
value of stemflow was 3.30\% in a secondary forest (SOUZA et al., 2007; GIGLIO; KOBIYAMA, 2013).

The average canopy cover index (CCI) considering all points was $75.0 \%$. The CCI of point Tf-70 was the lowest average. This point is located in the flattest part of the basin, where the trees are sparser in comparison to other monitoring points.

\section{Physicochemical parameters of water}

The conductivity, apparent color, dissolved solids and turbidity had the highest averages in samples from the stemflow than in the precipitation (Figure 4). According to Souza et al. (2007), this indicates that it would be occurring an increase in the concentration of ions associated with the presence of organic compounds dissolved in the solution. The $\mathrm{pH}$ decreased with the increase of DBH (Figure 4d).

The apparent color and conductivity were higher in Sf-31e. This tree is from the species Vernonanthura discolo with brown-grayish trunk and DBH of $31 \mathrm{~cm}$. In many occasions this stem was covered with mosses, which increases the entrainment of particulates in the water, making it darker and with greater conductivity.

In general, the highest average concentration of the physicochemical parameters was found in $S f-16 w$ point (Figure 4).
The trunk of this tree (Myrsine leathery) has a greyish outer shell, with small scales and large number of lenticels. Thus, similarly to what occurs in $S f-31$, the leaching process may cause an enrichment of the solid particles in the water.

The turbidity and total solids were greater in throughfall points Tf-88, Tf-87 and Tf-86 (Figure 4e and Figure 4f). During the monitoring period, it was observed the presence of lichens within these collection bottles which could be associated with this increased turbidity and solids content.

\section{Cluster and correlation analysis}

The cluster analysis was used to identify groups of points that presented similar behavior according to their physicochemical parameters. Among throughfall samples, it was not possible to verify a relationship between the groups formed and the physical parameters such as CCI or distance between the trees (Figure 5a).

In clustering stemflow it was possible to identify two distinct groups (Figure 5a). A group composed of points $S f-21 e$, $S f-23 w$ and $S f-31 e$ and another group by $S f-3 e, S f-13 e$ and $S f-14 w$. Trees with similar DBH were grouped together, showing that the $\mathrm{DBH}$ can be a good predictor of the physicochemical parameters of the stemflow. The water collected in $S f-16 w$ and points and

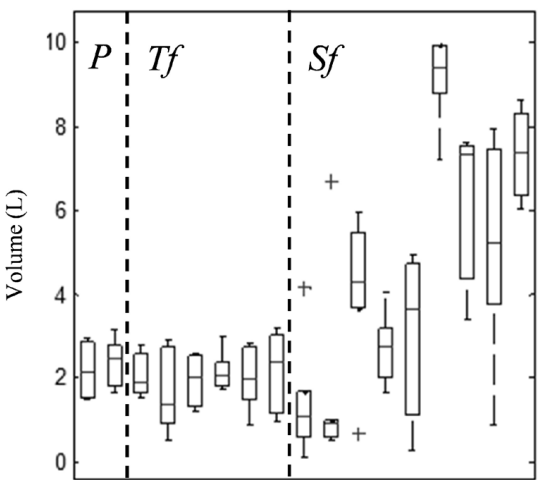

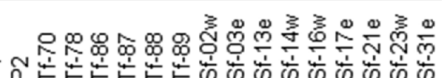

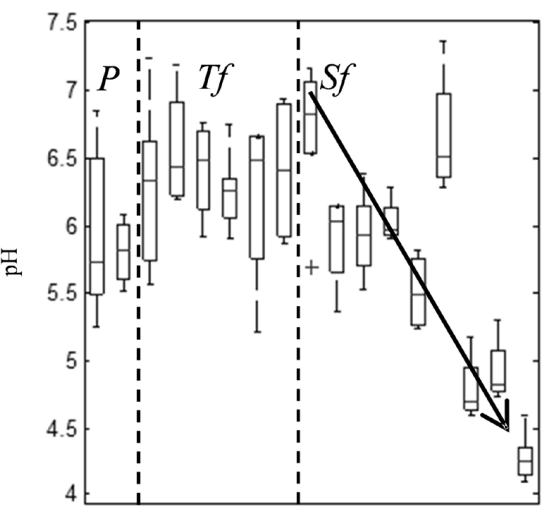

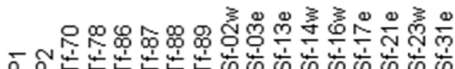

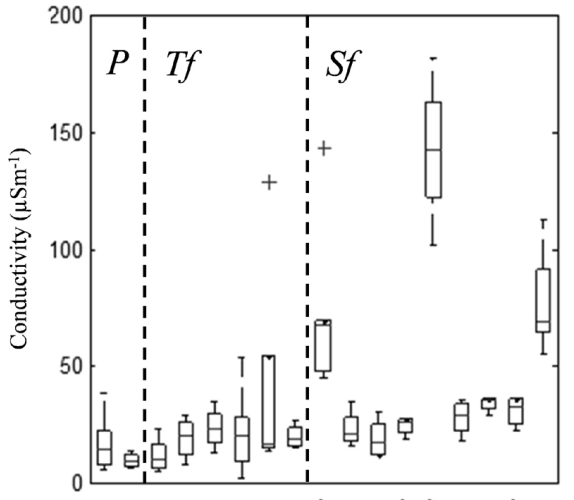

-

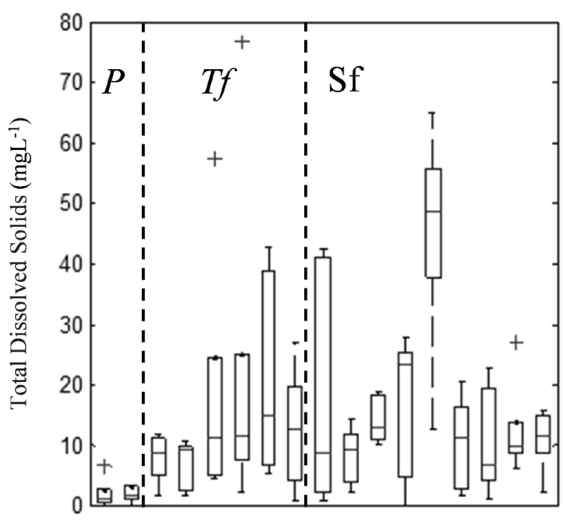

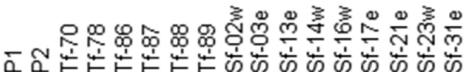

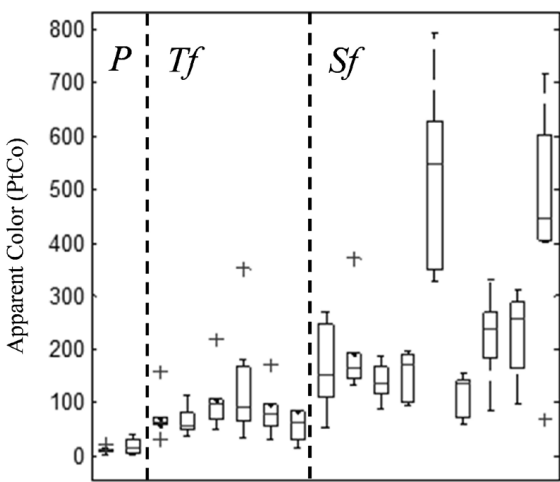

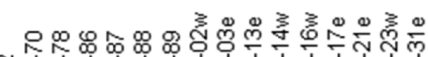

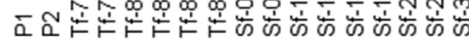

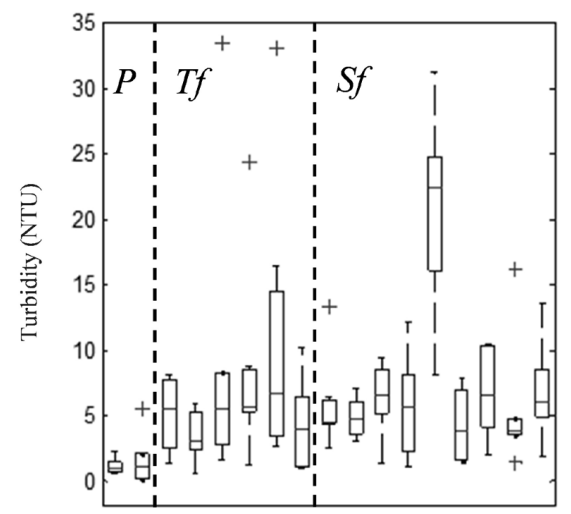

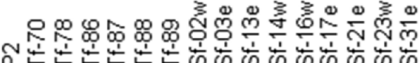

Figure 4. Boxplots of the physicochemical parameters in each of the monitoring points. Top and bottom of the box represent 25 and $75 \%$ of the sample, the line inside the box represents the median, the outliers are displayed with + and the dashed line represents the average of all points for each parameter. 


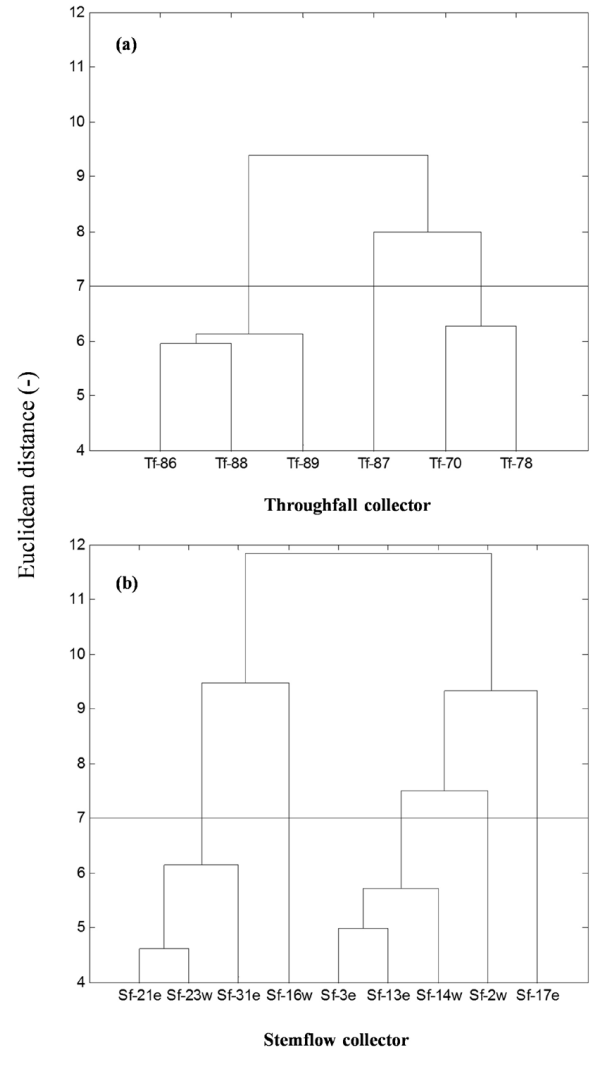

Figure 5. Clustering with complete linkage method using physicochemical parameters of the water. (a) throughfall $(\mathrm{n}=35)$ and $(\mathrm{b})$ stemflow $(\mathrm{n}=33)$.
$S f-17 e$ differs from most of the other points on the magnitude of the physicochemical parameters (Figure 4).

Regarding the stemflow samples, the $\mathrm{pH}$ was strongly correlated with three other parameters: the canopy area $\left(A_{\text {Canopv }}\right)$, diameter at breast height $(\mathrm{DBH})$ and color (Table 1). The higher the $\mathrm{DBH}$, the lower the $\mathrm{pH}$ value (Pearson's correlation coefficient was -0.75 and Spearman's coefficient was -0.71). In stemflow samples, conductivity was correlated to turbidity and color, considering both correlation coefficients (parametric and non-parametric). This is because the conductivity is directly related to dissolved ion concentrations or the concentration of nutrients.

$\mathrm{pH}$ value to throughfall samples was correlated with volume. The larger the volume, the lower the $\mathrm{pH}$ value. Their correlation coefficients were -0.72 (Pearson) and -0.65 (Spearman). No significant correlation between physicochemical parameters and CCI in throughfall points (Table 2) was observed.

\section{Ions analysis}

The vegetation influence on the concentration of the ions $\mathrm{NO}_{3}^{-}, \mathrm{Cl}, \mathrm{PO}_{4}^{3-}, \mathrm{SO}_{4}^{2-}, \mathrm{CH}_{3} \mathrm{CO}_{2}^{-}$and $\mathrm{Ca}^{2+}$ can be observed in Figure 6. Regarding precipitation, the $\mathrm{NO}_{3}^{-}$and $\mathrm{Ca}^{2+}$ levels in gross rainfall were in the same range found by Arcova, Cicco and Lima (1985). The stemflow (Sf-02w and $S f-31 e$ ) is richer in ions than throughfall (Tf-87 and Tf-88) and the precipitation (P1).

The increase of nutrients, especially of $\mathrm{Ca}^{2+}$ in the throughfall and stemflow is related to the presence of vegetation and decomposition of twigs and branches in the trees (SCHEER, 2009). The water that flows through the trunk has greater contact with vegetation than with the throughfall.

Table 1. The stemflow correlation matrix $(n=36)$. The upper diagonal presents the parametric Pearson's correlation and the lower diagonal nonparametric Spearman's correlation.

\begin{tabular}{ccccccccc}
\hline & $\boldsymbol{A}_{\text {canopy }}$ & $\mathbf{D B H}$ & Vol. & Turb. & Color & pH & Cond. & TDS \\
\hline$A_{\text {canopy }}$ & 1.00 & $\mathbf{0 . 9 0}$ & 0.33 & -0.21 & 0.24 & $-\mathbf{0 . 5 7}$ & 0.01 & -0.18 \\
DBH & $\mathbf{0 . 8 7}$ & 1.00 & $\mathbf{0 . 3 4}$ & 0.03 & $\mathbf{0 . 4 8}$ & $\mathbf{- 0 . 7 5}$ & 0.18 & 0.02 \\
Vol. & $\mathbf{0 . 4 7}$ & 0.31 & 1.00 & -0.12 & -0.14 & 0.01 & -0.18 & -0.09 \\
Turb. & -0.17 & 0.01 & -0.11 & 1.00 & $\mathbf{0 . 6 7}$ & -0.17 & $\mathbf{0 . 5 7}$ & $\mathbf{0 . 7 6}$ \\
Color & 0.17 & $\mathbf{0 . 4 9}$ & -0.08 & $\mathbf{0 . 5 3}$ & 1.00 & $\mathbf{- 0 . 6 7}$ & $\mathbf{0 . 8 1}$ & $\mathbf{0 . 5 1}$ \\
pH & $\mathbf{- 0 . 4 6}$ & $\mathbf{- 0 . 7 1}$ & 0.01 & -0.09 & $\mathbf{- 0 . 7 2}$ & 1.00 & -0.27 & -0.06 \\
Cond. & -0.04 & 0.24 & -0.13 & $\mathbf{0 . 4 0}$ & $\mathbf{0 . 7 3}$ & -0.31 & 1.00 & $\mathbf{0 . 4 8}$ \\
TDS & -0.25 & -0.13 & 0.03 & $\mathbf{0 . 7 9}$ & $\mathbf{0 . 4 6}$ & 0.07 & $\mathbf{0 . 4 2}$ & 1.00 \\
\hline
\end{tabular}

$A_{\text {canopy }}$ is the canopy area, DBH is the diameter at breast height, TDS is total dissolved solids. In bold are the significant correlations (p <0.05).

Table 2. The throughfall correlation matrix $(n=24)$. The upper diagonal present the parametric Pearson's correlation and the lower diagonal nonparametric Spearman's correlation.

\begin{tabular}{crrrrrrr}
\hline & CCI & Vol. & Turb. & Color & pH & Cond. & TDS \\
\hline CCI & 1.00 & -0.22 & 0.13 & 0.34 & 0.15 & $\mathbf{0 . 4 1}$ & 0.21 \\
Vol. & -0.27 & 1.00 & -0.29 & -0.16 & $\mathbf{- 0 . 7 2}$ & 0.21 & -0.21 \\
Turb. & 0.09 & -0.29 & 1.00 & $\mathbf{0 . 6 8}$ & -0.03 & 0.03 & $\mathbf{0 . 7 2}$ \\
Color & 0.28 & -0.32 & $\mathbf{0 . 6 6}$ & 1.00 & -0.06 & 0.38 & $\mathbf{0 . 7 2}$ \\
pH & 0.16 & $-\mathbf{0 . 6 5}$ & -0.12 & -0.08 & 1.00 & -0.33 & -0.19 \\
Cond. & 0.38 & 0.07 & -0.08 & $\mathbf{0 . 4 1}$ & -0.12 & 1.00 & 0.19 \\
TDS & 0.24 & -0.31 & $\mathbf{0 . 7 7}$ & $\mathbf{0 . 6 9}$ & -0.20 & 0.08 & 1.00 \\
\hline
\end{tabular}

CCI is canopy cover index, TDS is total dissolved solids. In bold are the significant correlations $(\mathrm{p}<0.05)$. 


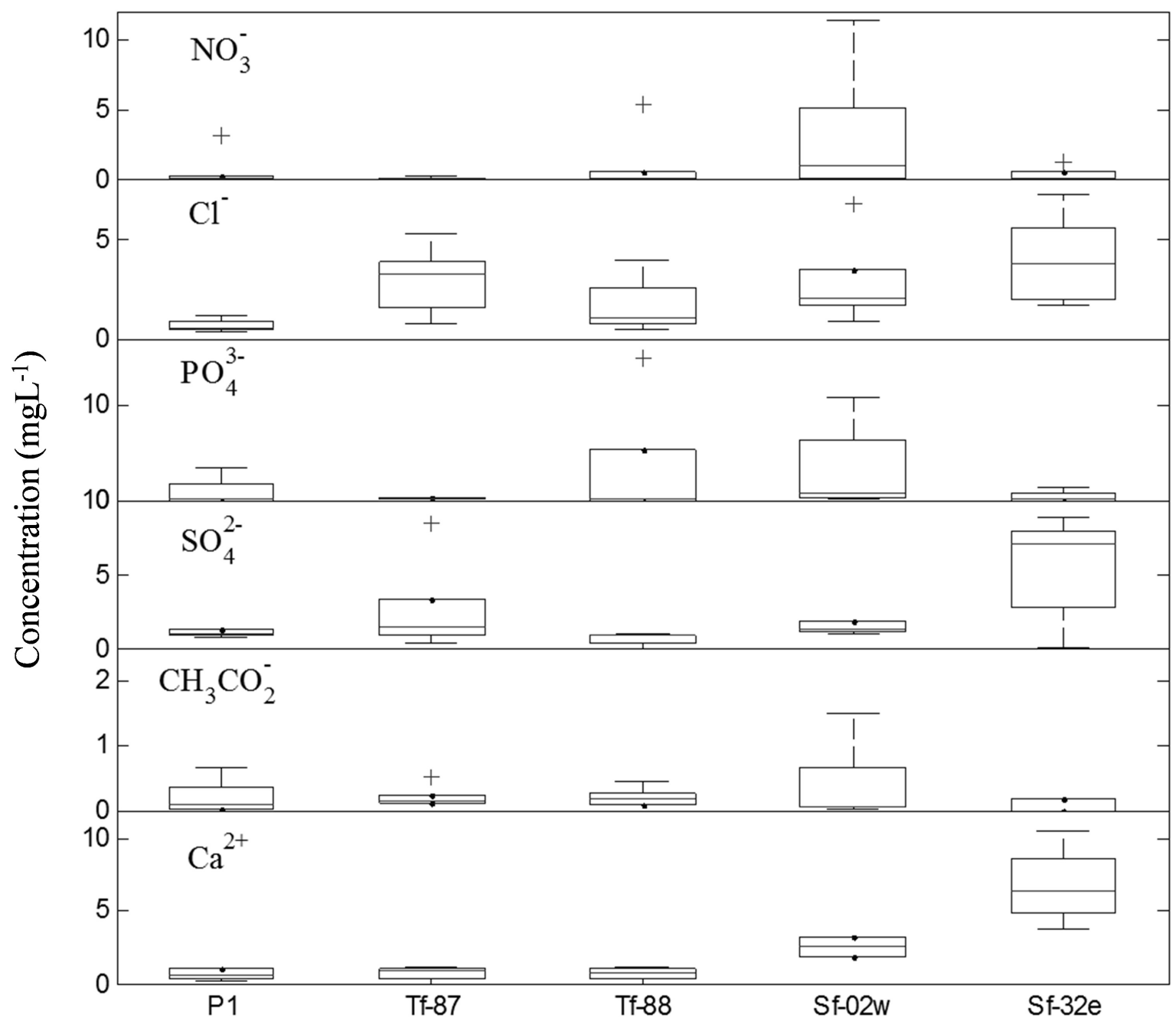

Figure 6. Boxplot of $\mathrm{NO}_{3}, \mathrm{Cl}, \mathrm{PO}_{4}^{3-}, \mathrm{SO}_{4}^{2-}, \mathrm{CH}_{3} \mathrm{CO}^{2-}$ and $\mathrm{Ca}^{2+}$ concentrations of the samples $S f-02 w$ and $S f-31 e$ (stemflow); Tf-87 and Tf-88 (throughfall); and precipitation $P 1(\mathrm{n}=4)$. Top and bottom of the box represent 25 and $75 \%$ of the sample, the line inside the box represents the median, the outliers are displayed with + .

This process of deposition and subsequent leaching might be the responsible for high amounts of $\mathrm{Ca}^{2+}$ and $\mathrm{SO}_{4}^{2-}$ concentrations in the stemflow samples. The concentrations of $\mathrm{NO}_{3}^{-}$and $\mathrm{PO}_{4}^{3-}$ showed no clear trend. In the case of $\mathrm{PO}_{4}^{3-}$, the point Tf-88 showed a high average.

\section{CONCLUSIONS}

In this study, we measured several water quality parameters in the interception process in a catchment covered with Subtropical Atlantic Forest. Conductivity parameters, apparent color, turbidity and dissolved solids showed on average higher values in stemflow samples than in the throughfall and precipitation. The results showed the influence of the interception process in water quality of throughfall and stemflow samples.

The greater contact with vegetation (leaves and bark of trees), has led to the higher turbidity, the apparent color, conductivity and concentrations of nutrients and minerals.

In general, the $\mathrm{pH}$ values decreased with the increase in $\mathrm{DBH}$. No significant correlation between physicochemical parameters and the canopy cover ratio was observed. The largest values of physicochemical parameters were found in $S f-16 w$ point, which can be attributed to characteristics of the species Myrsine coriacea. Lichens around the trunks were often present in $S f-31$ e point (Vernonanthura discolor), which may have contributed to the high color and conductivity values.

This study examined a period from July to November. We recommend a longer-term study to verify, whether there is influence of seasonality on the quality of water samples measured. The results of some stemflow samples may have been influenced by the species of the trees. Thus, it is suggested to choose more trees of the same species in order to determine the influence of morphological parameters that may determine the variation in ion concentration.

\section{ACKNOWLEDGMENTS}

Part of this study was funded FINEP, and project Manejo de águas pluviais em meio urbano - MAPLU (project $\mathrm{n}^{\circ} 17457$ ) and Rede de Pesquisa em Monitoramento e Modelagem de 
Processos Hidrossedimentológicos em Bacias Representativas Rurais e Urbana do Bioma Mata Atlântica - RIMA (project $\left.\mathrm{n}^{\circ} 3.07 .0058\right)$. The authors thank Prof. Masato Kobiyama UFRGS and Ma Joan Nery Giglio for the first installation of equipment for interception monitoring in the catchment and the members of the Laboratório de Hidrologia da UFSC, especially Debora Oliveira and Tássia Brighenti, for their help in the field and research; to Professor Rejane Helena Ribeiro da Costa, Professor Armando Borges Castilhos Junior and Dr. José Julio Barrios Restrepo for their assistance in the Laboratório Integrado de Meio Ambiente (LIMA-UFSC); to the three anonymous reviewers and the editor for the significant contribution to the improvement of the quality of the manuscript. The first author acknowledges the scholarship granted by CAPES and CNPq.

\section{REFERENCES}

ALVES, R. F.; DIAS, H. C. T.; OLIVEIRA JÚNIOR, J. C.; GARCIA, F. N. M. Avaliação da precipitação efetiva de um fragmento de Mata Atlântica em diferentes estágios de regeneração no município de Viçosa, MG. Revista Ambiente \& Água, v. 2, n. 1, p. 83-93, 2007.

APHA - AMERICAN PUBLIC HEALTH ASSOCIATION. Standard Methods For The Examination Of Water And Wastewater. 21 st ed. Washington, 2005.

ARCOVA, F. C. S.; CICCO, V. Fluxo de nutrientes através da precipitação, precipitação interna e escoamento pelo tronco em floresta natural secundária no Parque Estadual da Serra do Mar - Núcleo Cunha-SP. Boletim Técnico do Instituto Florestal, v. 41, n. 1, p. 37-58, 1987.

ARCOVA, F. C. S.; CICCO, V.; LIMA, W. P. Balanço dos nutrientes $\mathrm{Ca}+2, \mathrm{Mg}+2, \mathrm{Na}+1, \mathrm{~K}+1$ e NO3-1 em bacia hidrográfica experimental com vegetação natural do parque estadual da Serra do Mar-Núcleo Cunha, SP. Boletim Técnico do Instituto Florestal, v. 31, p. 61-67, 1985.

ARCOVA, F. C. S.; CICCO, V.; ROCHA, P. A. B. Precipitação efetiva e interceptação das chuvas por floresta de mata Atlântica em uma microbracia experimental em Cunha - São Paulo. Revista Árvore, v. 27, n. 2, p. 257-262, 2003.

ARCOVA, F. C. S.; CICCO, V.; SHIMOMICHI, P. Y. Qualidade da água e dinâmica dos nutrientes em bacia hidrográfica recoberta por floresta de Mata Atlântica. Revista do Instituto Florestal, v. 5, n. 1, p. 1-20, 1993.

ÁVILA, L. F.; MELLO, C. R.; PINTO, L. C.; SILVA, A. M. Partição da precipitação pluvial em uma microbacia hidrográfica ocupada por Mata Atlântica na Serra da Mantiqueira, MG. Ciência Florestal, v. 24 , n. 3, p. 583-595, 2014.

BALIEIRO, F. C.; FRANCO, A. A.; FONTES, R. L. F.; DIAS, L. E.; CAMPELLO, E. F. C.; FARIA, S. M. Evaluation of the throughfall and stemflow nutrient contents in mixed and pure plantations of Acacia mangium, Pseudosamenea guachapele and Eucalyptus grandis. Revista Arvore, v. 31, n. 2, p. 339-346, 2007. http://dx.doi. org/10.1590/S0100-67622007000200017.

BATALHA FILHO, H.; MIYAKI, C. Y. Filogeografia da Mata Atlântica. Revista da Biologia, p. 31-34, 2011. Volume especial.

BOUTEN, W.; HEIMOVAARA, T. J.; TIKTAK, A. Spatial patterns of throughfall and soil water dynamics in a Douglas fir stand. Water Resources Research, v. 28, n. 12, p. 3227-3233, 1992. http:// dx.doi.org/10.1029/92WR01764.

CALDATO, S. L.; SCHUMACHER, M. V. As unidades de conservação e a Floresta Ombrófila Mista no estado do Paraná. Ciência Florestal, v. 23, n. 3, p. 507-516, 2013.

CASTRO, P. S.; VALENTE, O. F.; COELHO, D. T.; RAMALHO, R. S. Interceptação da chuva por mata natural secundária na região de Viçosa, MG. Revista Árvore, v. 7, n. 1, p. 76-89, 1983.

CICCO, V.; ARCOVA, F. C. S.; SHIMOMICHI, P. Y.; FUJIEDA, M. Interceptação das chuvas por floresta natural secundária de Mata Atlântica - SP. Silvicultura em São Paulo, v. 20/22, p. 25-30, 1988.

CONCEIÇÃO, T. F.; SARDINHA, D. S.; NAVARRO, G. R. B.; ANTUNES, M. L. P.; ANGELUCCI, V. A. Rainwater chemical composition and annual atmospheric deposition in Sorocaba, (São Paulo state), Brazil. Brazilian Journal of Geophysics, v. 31, n. 1, p. 5-15, 2013.

DAVID, J.; VALENTE, F.; GASH, J. Evaporation of intercepted precipitation. In: ANDERSON, M. (Ed.), Encyclopedia of bydrological sciences. Chichester: John Wiley and Sons, 2005. chap. 43, p. 627-634.

DÍAZ, F. M.; BIGELOW, S.; ARMESTO, J. J. Alteration of the hydrologic cycle due to forest clearing and its consequences for rainforest succession. Forest Ecology and Management, v. 244, n. 1-3, p. 32-40, 2007. http://dx.doi.org/10.1016/j.foreco.2007.03.030.

DINGMAN, S. L. Precipitation. In: DINGMAN, S. L. Physical bydrology. 2nd ed. Upper Saddle River: Prentice Hall, 2002. chap. 4, p. $94-165$.

DINIZ, A. R.; PEREIRA, M. G.; BALIEIRO, F. C.; MACHADO, D. L.; MENEZES, C. E. G. Precipitação e aporte de nutrientes em diferentes estádios sucessionais de Floresta Atlântica, Pinheiral - RJ. Ciência Florestal, v. 23, n. 3, p. 389-399, 2013.

FORTI, M. C.; BICUDO, D. C.; BOUROT'TE, C.; CICCO, V.; ARCOVA, F. C. S. Precipitation and throughfall chemistry in the Atlantic Forest: a comparison between urban and natural areas. Hydrology and Earth System Sciences, v. 6, n. 6, p. 570-585, 2005. http://dx.doi.org/10.5194/hess-9-570-2005.

FREITAS, J. P. O.; DIAS, H. C. T.; BARROSO, T. H. A.; POYARES, L. B. Q. Distribuição da água de chuva em Mata Atlântica. Revista Ambiente e Agua, v. 8, n. 2, p. 100-108, 2013. 
GERRITS, A. M. J.; SAVENIJE, H. H. G. Interception. In: WILDERER, P. Treatise on water science. Oxford: Academic Press, 2011. v. 2, p. 89-101.

GIGLIO, J. N. Interceptação da chuva em pequena bacia experimental coberto por floresta Ombrófila Mista. 2013. 178 f. Dissertação (Mestrado em Engenharia Ambiental) - Universidade Federal de Santa Catarina, Florianópolis, 2013.

GIGLIO, J. N.; KOBIYAMA, M. Interceptação da chuva: uma revisão com ênfase no monitoramento em florestas brasileiras. Revista Brasileira de Recursos Hidricos, v. 18, n. 2, p. 297-317, 2013.

KEIM, R. F; SKAUGSET, A. E.; WEILER, M. Temporal persistence of spatial patterns in throughfall. Journal of Hydrology, v. 314, n. 1-4, p. 263-274, 2005. http://dx.doi.org/10.1016/j. jhydrol.2005.03.021.

KOICHIRO, K.; YURI, T.; NOBUAKI, T.; ISAMU, K. Generation of stemflow volume and chemistry in a mature Japanese cypress forest. Hydrological Processes, v. 15, n. 10, p. 1967-1978, 2001. http:/ / dx.doi.org/10.1002/hyp.250.

KRAMER, P. J.; BOYER, J. S. Transpiration and the ascent of sap. In: KRAMER, P. J.; BOYER, J. S. Water relations of plant and soils. San Diego: Academic Press, 1995. p. 201-256.

LACLAU, J. P.; RANGER, J.; BOUILLET, J. P.; NZILA, J. D.; DELEPORTE, P. Nutrient cycling in a clonal stand of Eucalyptus and an adjacent savanna ecossistem in Congo. 1. Chemical composition of the precipitation, througfall and the stemflow solutions. Forest Ecology and Management, v. 176, n. 1/3, p. 105-119, 2003. http://dx.doi.org/10.1016/S0378-1127(02)00280-3.

LORENZON, A. S.; DIAS, H. C. T.; LEITE, H. G. Precipitação efetiva e interceptação da chuva em um fragmento florestal com diferentes estágios de regeneração. Revista Árvore, v. 37, n. 4, p. 619627, 2013. http://dx.doi.org/10.1590/S0100-67622013000400005.

MELO, A. C. G.; MIRANDA, D. L. C.; DURIGAN, G. Cobertura de copas como indicador de desenvolvimento estrutural de reflorestamento de restauração de matas ciliares no médio vale do Paranapanema, SP, Brasil. Revista Árvore, v. 31, n. 2, p. 321-328, 2007.

MOSER, J. M. Solos. In: IBGE - INSTITUTO BRASILEIRO DE GEOGRAFIA E ESTATÍSTICA. Geografia do Brasil - Região Sul. Rio de Janeiro: IBGE, 1990. v. 2.

MOTA, A. A. Tempo de concentração em pequena bacia experimental. 2012. 131 f. Dissertação (Mestrado em Engenharia Ambiental) - Universidade Federal de Santa Catarina, Florianópolis, 2012.

MOURA, A. E. S. S.; CORREA, M. M.; SILVA, E. R.; FERREIRA, R. L. C.; FIGUEIREDO, A. C.; POSSAS, J. M. C. Interceptação da chuva em um fragmento de floresta da Mata Atlântica na Bacia do Prata, Recife, PE. Revista Árvore, v. 33, n. 3, p. 461-469, 2009.
MYERS, N.; MITTERMEIER, R. A.; MITTERMEIER, C. G.; FONSECA, G. A.; KENT, J. Biodiversity hotspots for conservation priorities. Nature, v. 403, n. 6772, p. 853-858, 2000. http://dx.doi. org/10.1038/35002501. PMid:10706275.

NAGHETTINI, M. C.; PINTO, E. J. A. Hidrologia estatística. Belo Horizonte: CPRM, 2007.

NASCIMENTO, A. R. T.; FAGG, J. M. F.; FAGG, C. W. Canopy openness and LAI estimates in two seasonally deciduous forests on limestone outcrops in central Brazil using hemispherical photographs. Revista Árvore, v. 31, n. 1, p. 167-176, 2007. http:/ / dx.doi.org/10.1590/S0100-67622007000100019.

OLIVEIRA JUNIOR, J. C.; DIAS, H. C. T. Precipitação efetiva em fragmentos secundário da Mata Atlântica. Revista Árvore, v. 29, n. 1, p. 9-15, 2005. http://dx.doi.org/10.1590/S010067622005000100002 .

PIRES, P. T. L.; ZENI JUNIOR, D. M., GAULKE, D. As unidades de conservação e a Floresta Ombrófila Mista no estado do Paraná. Revista Ciência Florestal, v. 22, n. 3, p. 589-603, 2012.

SÁ, J. H. M.; CHAFFE, P. L. B.; OLIVEIRA, D. Y. Análise comparativa dos modelos de Gash e de Rutter para a estimativa da interceptação por Floresta Ombrófila Mista. Revista Brasileira de Recursos Hídricos, v. 20, n. 4, p. 1008-1018, 2015. http://dx.doi. org/10.21168/rbrh.v20n4.p1008-1018.

SARI, V.; PAIVA, E. M. C. D.; PAIVA, J. B. D. Interceptação da chuva em diferentes formações florestais na região sul do Brasil. Revista Brasileira de Recursos Hídricos, v. 21, n. 1, p. 65-79, 2016. http://dx.doi.org/10.21168/rbrh.v21n1.p65-79.

SARI, V.; PAIVA, E. M. C. D.; PAIVA, J. B. D. Precipitação interna em Floresta Atlântica: comparação entre os sistemas de monitoramento fixo e móvel. Revista Brasileira de Recursos Hídricos, v. 20, n. 4, p. 849-861, 2015. http://dx.doi.org/10.21168/rbrh. v20n4.p849-861.

SCHEER, M. B. Fluxo de nutrientes pela precipitação pluviométrica em dois trechos de floresta ombrófila densa em Guaraqueçaba, Paraná. Revista Floresta, v. 39, n. 1, p. 117-130, 2009.

SOUZA, L. C.; MARQUES, R. Fluxo de nutrientes em Floresta Ombrófila Densa das terras baixas no litoral do Paraná. Revista Floresta, v. 40, n. 1, p. 125-136, 2010.

SOUZA, V. V.; DIAS, H. C. T.; COSTA, A. A.; OLIVEIRA JUNIOR, J. C. Análise da qualidade das águas das precipitações em aberto e efetiva em um fragmento secundário da Mata Atlântica, no município de Viçosa, MG. Revista Árvore, v. 31, n. 4, p. $737-743,2007$.

STAELENS, J.; SCHRIJVER, A. D.; VERHEYEN, K.; VERHOEST, N. E. C. Spatial variability and temporal stability of throughfall water under a dominant beech (Fagus sylvatica L.) tree in relationship 
to canopy cover. Journal of Hydrology, v. 330, n. 3-4, p. 651-662, 2006. http://dx.doi.org/10.1016/j.jhydrol.2006.04.032.

THOMAZ, E. L. Avaliação de interceptação e precipitação interna em capoeira e floresta secundária em Guarapuava-PR. Geografia, v. 14 , n. 1 , p. 47-60, 2005.

TOGASHI, H. F.; MONTEZUMA, R. C. M.; LEITE, A. F. Precipitação incidente e fluxo de atravessamento das chuvas em três estágios sucessionais de floresta atlântica no maciço da pedra branca, Rio de Janeiro. Revista Árvore, v. 36, n. 5, p. 907-917, 2012.

TONELLO, K. C.; GASPAROTO, E. A. G.; SHINZATO, E. T.; VALENTE, R. O. A.; DIAS, H. C. T. Precipitação efetiva em diferentes formações florestais na floresta nacional de Ipanema. Revista Árvore, v. 38, n. 2, p. 383-390, 2014.

WUYTS, K.; SCHRIJVER, A. D.; STAELENS, J.; VERHEYEN, $\mathrm{K}$. Comparison of forest edge effects on throughfall deposition in different forest types. Environmental Pollution, v. 156, n. 3, p. 854-861, 2008. http://dx.doi.org/10.1016/j.envpol.2008.05.018. PMid:18783861.

\section{Authors contributions}

João Henrique Macedo Sá: he designed the experiment, installed the equipment, were responsible for monitoring, analysis in laboratory and wrote the article.

Pedro Luiz Borges Chaffe: he designed the experiment and wrote the article.

Matthieu Jack Joseph Quillet: he installed the equipment and were responsible for monitoring and analysis in laboratory. 